\title{
Brine shrimp (Artemia salina Leach) bioassay of extracts from Lychnophoriopsis candelabrum and different Lychnophora species
}

FERRAZ FILHA, Z.S. ${ }^{\text {; }}$ LOMBARDI, J. A. ${ }^{2}$; GUZZO, L.S. ${ }^{1}$; SAÚDE-GUIMARÃES, D.A. ${ }^{\text {* }}$

${ }^{1}$ Laboratório de Plantas Medicinais (LAPLAMED), Departamento de Farmácia, Escola de Farmácia, Universidade Federal de Ouro Preto (UFOP), Rua Costa Sena, 171-Centro, CEP: 35.400-000, Ouro Preto-Brazil *saude@ef.ufop.br ${ }^{2}$ Departamento de Botânica, Instituto de Biociências de Rio Claro, UNESP, CEP: 13.506-900, Rio Claro-Brazil

\begin{abstract}
RESUMO: O presente estudo teve como objetivo avaliar a citotoxicidade sobre Artemia salina de vinte e dois extratos de cinco espécies do gênero Lychnophora e de uma espécie de Lychnophoriopsis. Os extratos solubilizados em DMSO, preparados nas concentrações finais de $100,250,375,500$ e $600 \mathrm{~g} \mathrm{~mL}^{-1}$, foram adicionados a recipientes contendo náuplios de Artemia salina (10 unidades cada) e completou-se o volume para $5 \mathrm{~mL}$ com solução marinha. Lapachol e DMSO $5 \%$ foram usados como controles positivo e negativo, respectivamente. As amostras foram mantidas sob iluminação e as larvas mortas foram contadas após 24 horas de contato. $O$ cálculo da $\mathrm{LC}_{50}$ foi feito utilizando-se o programa Probitos. Os extratos etanólicos brutos de cinco espécies apresentaram baixa letalidade na seguinte ordem: $L y$ chnophora trichocarpha $\left(\mathrm{LC}_{50}=672,38\right.$ $\left.\mu \mathrm{g} \mathrm{mL}^{-1}\right)>$ Lychnophora pinaster $\left(\mathrm{LC}_{50}=678,73 \mu \mathrm{g} \mathrm{mL}-1\right)>$ Lychnophora ericoides $\left(\mathrm{LC}_{50}=738,09 \mu \mathrm{g}\right.$ $\left.\mathrm{mL}^{-1}\right)>$ Lychnophoriopsis candelabrum $\left(\mathrm{LC}_{50}=812,57 \mu \mathrm{g} \mathrm{mL}^{-1}\right)>$ Lychnophora passerina $\left(\mathrm{LC}_{50}=\right.$ $921,78 \mu \mathrm{g} \mathrm{mL}^{-1}$ ). Todos os extratos testados de Lychnophoriopsis candelabrum e o extrato clorofórmico de Lychnophora staavioides mostraram leve toxicidade sobre $A$. salina. Os resultados indicaram que existem substâncias com potencial atividade farmacológica em todas as espécies testadas.
\end{abstract}

Palavras-chave: Lychnophora, Lychnophoriopsis, Artemia salina, citotoxicidade

\begin{abstract}
Brine shrimp (Artemia salina Leach) bioassay of extracts from different Lychnophora species. The present study aimed to evaluate on Artemia salina the citotoxicity of twenty-two extracts from five species of the genus $L y c h n o p h o r a$ and one species of the genus Lychnophoriopsis. The extracts solubilized in DMSO and prepared at the final concentrations of $100,250,375,500$ and $600 \mu \mathrm{g} \mathrm{mL}^{-1}$ were added to tubes containing Artemia salina nauplii (10 units each) and filled to $5 \mathrm{~mL}$ total volume with artificial salt water. Lapachol and $5 \%$ DMSO were used as positive and negative controls, respectively. The samples were kept under light and dead larvae were counted after 24 hours of contact. LC $_{50}$ was calculated by using Probit software. The crude ethanol extracts from five species showed low lethality in the following order: Lychnophora trichocarpha $\left(\mathrm{LC}_{50}=672.38 \mu \mathrm{g} \mathrm{mL}^{-1}\right)>$ Lychnophora pinaster $\left(\mathrm{LC}_{50}=678.73 \mu \mathrm{g} \mathrm{mL}^{-1}\right)>$ Lychnophora ericoides $\left(\mathrm{LC}_{50}=738.09 \mu \mathrm{g} \mathrm{mL}^{-1}\right)>$ Lychnophoriopsis candelabrum $\left(\mathrm{LC}_{50}=812.57 \mu \mathrm{g} \mathrm{mL}^{-1}\right)>$ Lychnophora passerina $\left(\mathrm{LC}_{50}=921.78 \mu \mathrm{g} \mathrm{mL}^{-1}\right)$. All tested extracts from $L$. candelabrum and chloroform extract from $L$. staavioides showed light toxicity on $A$. salina. Results indicated that there are substances with potential pharmacological activity in all tested species.
\end{abstract}

Key words: Lychnophora, Lychnophoriopsis, Artemia salina, cytotoxicity

\section{INTRODUCTION}

The genus Lychnophora (Asteraceae) is restricted to Brazilian Cerrado (Robinson, 1999). The shoots and roots of a large number of Lychnophora species are widely used in Brazilian folk medicine. They are macerated in water, ethanol, or "cachaça" (sugar cane spirit), administered by oral route or used topically and as anti-inflammatory to treat bruises, pain, and rheumatism (Saúde et al., 1998; Guzzo et al., 2008). In Brazil, these species are popularly known as "arnica brasileira", "falsa arnica", or "arnica da serra" because their smell is similar to that of Arnica montana L. species (Cerqueira et al., 1987).

The analgesic and anti-inflammatory activities of Lychnophoras extracts and their constituents have

Recebido para publicação em 10/05/2011

Aceito para publicação em 20/03/2012

Rev. Bras. PI. Med., Botucatu, v.14, n.2, p.358-361, 2012. 
already been reported (Cerqueira et al.; 1987; Borsato et al., 2000; Gobbo-Neto et al., 2005; Santos et al., 2005; Ferraz-Filha et al., 2006; Guzzo et al., 2008), showing that this species has prospects of use in the treatment of pain and inflammation.

Artemia salina, commonly known as the brine shrimp, is a small crustacean, which has been the subject of many studies. The brine shrimp lethality assay is considered one of the most useful tools for the preliminary assessment of general toxicity. It has been established as a safe, practical and economic method to determine the bioactivity of plant products (Subhan et al., 2008). The aim of this method is to provide a front-line screen that can be backed up by more specific and more expensive bioassays once the active compounds have been isolated.

Considering that Lychnophora species are used in the crude extract and are able to have phytoconstituents with unknown activities, the present study was conducted to comparatively verify the in vitro cytotoxic activity of ethanol extracts and fractions from five Lychnophora species and one Lychnophoriopsis species. Lychnophoriopsis candelabrum was included in this study because at the beginning of the experiment it was classified as belonging to the genus Lychnophora (Santos et al., 2005).

\section{MATERIALAND METHOD}

\section{Plant material}

Shoots of botanically identified Lychnophoriopsis candelabrum (Schultz-Bip.) H. Robinson (LC), Lychnophora ericoides Mart. (LE), Lychnophora passerina (Mart.exDC.) Gardn. (LPa) and Lychnophora staavioides Mart. (LS) were harvested in September 2000. Lychnophora pinaster Mart. (LPi) was harvested in March 2003. Voucher specimens were deposited at the Herbarium of Institute of Biological Sciences (BHCB)", Federal University of Minas Gerais (UFMG), Belo Horizonte, Minas Gerais State, Brazil, under the reference numbers 53566, 53568, 53571, 53570 and 19520, respectively. Lychnophora trichocarpha Spreng. (LT) was harvested in October 2003, and a voucher specimen no 20635 was deposited at the Herbarium of Institute of Biological and Exact Sciences, Federal University of Ouro Preto (UFOP), Ouro Preto, Minas Gerais State, Brazil. The species were identified by the botanist Dr. Júlio Antônio Lombardi.

\section{Preparation of plant extracts}

The shoots of the species LC, LE, LPa, LS, $\mathrm{LPi}$ and $\mathrm{LT}$ were dried at $40^{\circ} \mathrm{C}$ for 1 week and reduced to powder. Then, $800 \mathrm{~g}$ of each species were extracted with ethanol, by percolation, at room temperature, for 2 weeks. The solvent was removed under reduced pressure to obtain $13.6,5.6,5.7,2.3,4.6$ and $6.4 \%$ $(\mathrm{w} / \mathrm{w})$ of dry crude ethanol extracts called LCE, LEE, LPaE, LSE, LPiE and LTE, respectively. In addition, the shoots of $L$. candelabrum (LC, $2.0 \mathrm{~kg}$ ) and $L$. staavioides (LS, $3.0 \mathrm{~kg}$ ) were extracted by percolation, at room temperature, for 2 weeks, successively using hexane, chloroform and ethanol. The solvent was removed under reduced pressure to yield, respectively, hexanic (LC1, $33.0 \mathrm{~g}$; LS1, $79.0 \mathrm{~g}$ ), chloroformic (LC2, $22.0 \mathrm{~g}$; LS2, $44.0 \mathrm{~g}$ ) and ethanol (LC3, $22.0 \mathrm{~g}$; LS3, $90.0 \mathrm{~g})$ dry extracts. The shoots of $L$. trichocarpha (LT) $(1.4 \mathrm{Kg})$ were extracted exhaustively with ethyl acetate and methanol to obtain ethyl acetate (LT1, $20.0 \mathrm{~g}$ ) and methanol (LT2, $26.3 \mathrm{~g}$ ) extracts, respectively. The crude ethanol extracts $L P a E, L P i E$ and LEE were subjected to extraction with hexane, ethyl acetate and ethanol to yield, respectively, hexanic (LPa1, $0.446 \mathrm{~g}$; LPi1, $0.550 \mathrm{~g}$; LE1, $0.350 \mathrm{~g}$ ), ethyl acetate (LPa2, $0.700 \mathrm{~g}$; LPi2, $0.370 \mathrm{~g}$; LE2, $0.700 \mathrm{~g}$ ), and methanol extracts (LPa3, $0.350 \mathrm{~g}$; LPi3, 0,383 g; LE3, $0.200 \mathrm{~g}$ ). The solvents were completely removed under vacuum.

\section{Cytotoxic activity}

The cytotoxicity of extracts was evaluated by Artemia salina lethality test according to the procedure described by Meyer et al. (1982). Encysted eggs of the brine shrimp Artemia salina Leach were incubated in artificial seawater and exposed to a 60W lamp, pH 8-9. After $48 \mathrm{~h}$, the nauplii (10 units) were added to each set of tubes containing crude ethanol extract dissolved in 5\% DMSO andfilled to $5 \mathrm{~mL}$ total volume with artificial salt water. The extracts were tested in triplicate at 100, 250,375, 500 and $600 \mu \mathrm{g}$ $\mathrm{mL}^{-1}$. Lapachol and 5\% DMSO were used as positive and negative controls, respectively. After $24 \mathrm{~h}$, the number of survivors was counted and the percentage of death calculated. The lethal concentration $50 \%$ (LC $_{50}$ value) and the standard error were calculated by Probit analysis (Finney, 1971).

\section{RESULT AND DISCUSSION}

In the present study, brine shrimp lethality assay was carried out to evaluate the cytotoxicity of extracts from different $L y c h n o p h o r a$ species. Results are shown in Table 1.

According to Nguta et al. (2011), crude extracts with $\mathrm{LC}_{50}$ values less than $100 \mu \mathrm{g} \mathrm{mL}^{-1}$ are considered highly toxic, those with $\mathrm{LC}_{50}$ values between $100 \mu \mathrm{g} \mathrm{mL}^{-1}$ and $500 \mu \mathrm{g} \mathrm{mL}^{-1}$, moderately toxic, the ones with $\mathrm{LC}_{50}$ values between $500 \mu \mathrm{g} \mathrm{mL}^{-1}$ and $1000 \mu \mathrm{g} \mathrm{mL}^{-1}$, mildly toxic, and those with $\mathrm{LC}_{50}$ values above $1000 \mu \mathrm{g} \mathrm{mL}^{-1}$ are considered non-toxic.

Of the twenty-two tested extracts, thirteen had $\mathrm{LC}_{50}$ between 500 and $1000 \mu \mathrm{g} \mathrm{mL}^{-1}$, showing weak toxicity. The crude ethanol extracts of five tested 
species had mild cytotoxicity in the following order: LTE > LPiE > LEE > LCE > LPaE. The ethanol extract from $L$. staavioides (LSE) showed no cytotoxicity. This result may indicate a good prospect of use of $L$. staaviodes which showed anti-rheumatic activity (Ferraz Filha et al., 2006). However, further toxicity studies should be performed to verify the non-toxicity of $L$. staavioides and the actual feasibility of using this species. Every tested $L$. candelabrum extract (LCE, LC1, LC2 and LC3) showed mild cytotoxicity. Additionally, LS2, LTE, LT2, LE1, LE2 and LPi2 extracts showed higher larvicidal activity.

Previous phytochemical studies involving Lychnophoriopsis candelabrum (Santos et al., 2004) obtained terpenoids and flavonoids. A large number of Lychnophora species have been the focus of phytochemical studies, providing terpenes, steroids and flavonoids as their major compounds (Oliveira et al., 1996; Borella et al., 1998; Saúde et al., 1998;

TABLE 1. Larvicidal activity of plant extracts against brine shrimp.

\begin{tabular}{|c|c|c|}
\hline Species & $\begin{array}{c}\text { Tested } \\
\text { extracts }\end{array}$ & $\begin{array}{c}\mathrm{LC}_{50} \\
\left(\mu \mathrm{g} \mathrm{mL}^{-1}\right)\end{array}$ \\
\hline \multirow[t]{4}{*}{ Lychnophoriopsis candelabrum } & LCE & 812.57 \\
\hline & LC1 & 703.61 \\
\hline & LC2 & 722.17 \\
\hline & LC3 & 815.49 \\
\hline \multirow[t]{4}{*}{ Lychnophora passerina } & LPaE & 921.78 \\
\hline & LPa1 & 1978.81 \\
\hline & LPa2 & 13731.59 \\
\hline & LPa3 & 1674.66 \\
\hline \multirow[t]{4}{*}{ Lychnophora staavioides } & LSE & 1463.18 \\
\hline & LS1 & NT \\
\hline & LS2 & $<600$ \\
\hline & LS3 & 1128.99 \\
\hline \multirow[t]{3}{*}{ Lychnophora trichocarpha } & LTE & 672.38 \\
\hline & LT1 & 7035.79 \\
\hline & LT2 & 720.25 \\
\hline \multirow[t]{4}{*}{ Lychnophora ericoides } & LEE & 738.09 \\
\hline & LE1 & 660.96 \\
\hline & LE2 & 546.23 \\
\hline & LE3 & 7487.88 \\
\hline \multirow[t]{4}{*}{ Lychnophora pinaster } & LPiE & 678.73 \\
\hline & LPi1 & 2276.14 \\
\hline & LPi2 & 694.60 \\
\hline & LPi3 & 3663.35 \\
\hline Lapachol & - & 52.4785 \\
\hline
\end{tabular}

NT - not tested
Sakamoto et al., 2003; Gobbo-Neto et al., 2005). Sesquiterpene lactones are common compounds that appear in the genus Lychnophora (Costa et al., 2005) which presented cytotoxic activity in previous studies (Kupchan et al., 1971; Rodriguez et al., 1976). Lychnopholide, a sesquiterpene lactone present in $L$. trichocarpha (Saúde et al., 1998) and L. ericoides (Sakamoto et al., 2003), was evaluated by an in vitro disease-oriented antitumor screening, which determines antitumor effects against a panel of approximately 60 human tumor cell lines. Lychnopholide showed significant activity against 33 tumor cell lines showing values of $\mathrm{LC}_{50} \leq 4.6 \mu \mathrm{g} \mathrm{mL}^{-1}$ (Saúde-Guimarães, 1998).

The brine shrimp lethality assay has shown good correlation with trypanocidal (Zani et al., 1995), antitumor and pesticidal activities (McLaughlin et al., 1998). The trypanocidal activity of extracts and compounds from $L$. passerina, $L$. pinaster and $L$. trichocarpha has already been shown. In previous studies, lychnopholide showed trypanocidal activity against tripomastigote strains of Trypanosoma cruzi (Oliveira et al., 1996).

Although in plant extracts the substances are usually found at low concentrations, the results of this study indicate that thirteen extracts obtained from all tested species may contain substances with potential biological activity.

\section{ACKNOWLEDGMENT}

The authors would like to thank FAPEMIG (Fundação de Amparo à Pesquisa do Estado de Minas Gerais, 193/05), CNPQ (Conselho Nacional de Pesquisa) and UFOP (Universidade Federal de Ouro Preto) for financial support. Luciana Souza Guzzo and Zilma Ferraz Filha thank the CAPES and UFOP respectively for their fellowship.

\section{REFERENCE}

BORELLA, J.C. et al. Sesquiterpene lactones, triterpenes and flavones from Lychnophora ericoides and Lychnophora pseudovillosissima. Biochemical Systematics and Ecology, v.26, p.671-6, 1998.

BORSATO, M.L. et al. Analgesic activity of the lignans from Lychnophora ericoides. Phytochemistry, v.55, n.7, p.809-13, 2000.

CERQUEIRA, M.B.S. et al. Ação analgésica do extrato bruto aquoso liofilizado do caule e folhas da Lychnophora ericoides Mart. (arnica). Ciência e Cultura, v.39, n.5/6, p.551-3, 1987.

COSTA, F.B.; TERFLOTH, L.; GASTEIGER, J. Sesquiterpene lactone-based classification of three Asteraceae tribes: a study based on self-organizing neural networks applied to chemosystematics. Phytochemisty, v.66, n.3, p.345-53, 2005.

FERRAZ FILHA, Z.S. et al. Xanthine oxidase inibitory

Rev. Bras. PI. Med., Botucatu, v.14, n.2, p.358-361, 2012. 
activity of Lychnophora species from Brazil ("Arnica"). Journal of Ethnopharmacology, v.107, n.1, p.79-82, 2006. FINNEY, D.J. Probit analysis. 3.ed. New York: Cambridge University Press, 1971. 333p.

GOBBO-NETO, L. et al. Evaluation of the anti-inflammatory and antioxidant activities of di-C-glucosylflavones from Lychnophora ericoides (Asteraceae). Planta Medica, v.71, n.1, p.3-6, 2005

GUZZO, L.S. et al. Antinociceptive and anti-inflammatory activities of ethanolic extracts of Lychnophora species. Journal of Ethnopharmacology, v.116, n.1, p.120-4, 2008. KUPCHAN, S.M.; EAKIN, M.A.; THOMAS, A.M. Tumor inhibitors. 69. structure-cytotoxicity relationships among the sesquiterpene lactones. Journal of Medicinal Chememistry, v.14, n.12, p.1147-52, 1971.

NGUTA, J.M. et al. Biological screening of kenya medicinal plants using Artemia salina L. (Artemiidae). Pharmacologyonline, v.2, p.458-78, 2011.

MEYER, B.N. et al. Brine shrimp: a convenient general bioassay for active plant constituents. Planta Medica, v.45, n.5, p.31-4, 1982.

OLIVEIRA, A.B. et al. Trypanocidal sesquiterpenes from Lychnophora species. Phytotherapy Research, v.10, n.4, p.292-5, 1996.

ROBINSON, H. Generic and sub-tribal classification of American Vernonieae. Smithsonian Contributions to
Botany, v.89, p.1-116, 1999

RODRIGUEZ, E.; TOWERS, G.H.N.; MITCHELL, J.C. Biological activities of sesquiterpene lactones. Phytochemistry, v.15, n.11, p.1573-80, 1976.

SAKAMOTO, H.T. et al. Sesquiterpene lactones from Lychnophora ericoides. Journal of Natural Products, v.66, n.5, p.693-5, 2003.

SANTOS, P.A.; LOPES, J.L.C.; LOPES, N.P. Triterpenoids and flavonoids from Lychnophoriopsis candelabrum (Asteraceae). Biochemical Systematics and Ecology, v.32, n.5, p.509-12, 2004.

SANTOS, M.D. et al. Analgesic activity of di-caffeoylquinic acids from roots of Lychnophora ericoides (Arnica da Serra). Journal of Ethnopharmacology, v.96, n.3, p.5459, 2005.

SAÚDE-GUIMARÃES, D.A. Transformações químicas, microbiológicas e atividades biológicas de lactonas sesquiterpênicas. 1998. 270p. Tese (Doutorado em Química Orgânica) - Departamento de Química, Universidade Federal de Minas Gerais, Belo Horizonte. SUBHAN, N. et al. Bioactivity of Excoecaria agallocha. Revista Brasileira de Farmacognosia, v.18, n.4, p.5216, 2008.

ZANI, C.L. et al. Brine shrimp lethality assay as a prescreening system for anti-Trypanosoma cruzi activity. Phytomedicine, v.2, n.1, p.47-50, 1995. 